\title{
PEMBERDAYAAN MASYARAKAT BINAAN RUMAH TAHANAN PONDOK BAMBU, JAKARTA DALAM PEMENUHAN HAK-HAK TERSANGKA
}

\author{
Amoury Adi Sudiro ${ }^{1 *}$, Suartini ${ }^{1}$ \\ ${ }^{1}$ Ilmu Hukum, Fakultas Hukum, Universitas Al Azhar Indonesia \\ Jalan Sisingamangaraja, Kompleks Masjid Agung Al Azhar, Kebayoran Baru, Jakarta Selatan 12110 \\ Email Penulis Korespondensi: amourysudiro@uai.ac.id
}

\begin{abstract}
Abstrak
Rumah Tahanan Pondok Bambu terletak di Jalan Pahlawan Revolusi, Kelurahan Pondok Bambu, Kecamatan Duren Sawit, Jakarta Timur. Data penghuni rumah tahanan tersebut adalah dihuni 401 orang terdiri atas 380 narapidana, 16 tahanan dan lima orang anak di bawah umur. Permasalahan yang terjadi pada rumah tahanan adalah belum seluruhnya penghuni mengetahui hak-hak yang dia harus dapatkan ketika mereka dijadikan tersangka dan menjadi penghuni rumah tahanan. Hal ini disebabkan oleh karena ketidakpahaman mereka terkait undang-undang yang telah mengatur hakhak tersebut. Negara melindungi warganya termasuk orang yang melakukan tindak pidana, dan mereka tetap memiliki hak-hak sebagaimana telah diatur dalam peraturan perundang-undangan selama masa tahanan atau ketika mereka menghadapi persidangan sampai pasca putusan hakim. Penyuluhan hukum dibutuhkan oleh para tersangka atau terdakwa karena terdapat banyak hak-hak yang seharusnya mereka peroleh, tetapi mereka tidak tahu bahkan mereka mengabaikannya karena ketidaktahuan atau kurangnya pengetahuan mereka terhadap hak-hak tersebut. Metode penyuluhan itu dilakukan dengan cara memberikan pemaparan dan konsultasi serta pendampingan terhadap hakhak tersangka dengan tujuan pembinaan bagi tersangka atau terdakwa yang melibatkan para pemberi bantuan hukum sehingga nantinya dapat menghasilkan semangat pembinaan bangsa melalui pemenuhan hak-hak mereka.
\end{abstract}

Kata Kunci : Pembinaan, Masyarakat, Rumah Tahanan

\begin{abstract}
Pondok Bambu Detention House is located on Jalan Pahlawan Revolusi, Pondok Bambu Village, Duren Sawit District, East Jakarta. Data on the occupants of the detention house is inhabited by 401 people consisting of 380 inmates, 16 detainees, and five underage children. The problem that occurs in a detention house is that not all residents know the rights that they must get when they are made suspects and become residents of detention. This is due to their lack of understanding regarding the laws governing those rights. The state protects its citizens including those who commit a criminal offense, and they retain the rights as stipulated in the legislation during the detention period or when they face trial until after the judge's decision. Legal counseling is needed by suspects or defendants because there are many rights that they should have, but they do not know even they are ignoring them because of ignorance or lack of knowledge about these rights. The counseling method is carried out by providing exposure and consultation as well as assistance to the rights of suspects to faster suspects or defendants involving legal aid providers so that later they can produce the spirit of national development through the fulfillment of their rights.
\end{abstract}

Keywords:Coach, Detention house, Community. 


\section{PENDAHULUAN}

Ketidakpahaman para tersangka terhadap hak-hak mereka membuat mereka tidak mengerti apa yang seharusnya dapat mereka lakukan dalam persiapan persidangan maupun selama persidangan. Hak-hak tersangka yang ditahan dalam Rumah Tahanan sudah diatur dalam peraturan perundang-undangan sebagai upaya pemenuhan hak-hak mereka, namun masih banyak yang tidak mengetahui hal tersebut dikarenakan kurangnya sosialisasi kepada para tersangka dalam rutan. Melalui penyuluhan hukum yang dilakukan dalam Rumah Tahanan dapat meningkatkan kesadaran dan pemahaman penghuni rutan khususnya para tersangka yang ditahan di Rumah Tahanan. Sosialisasi hak-hak tersangka melalui penyuluhan adalah upaya pemerintah dengan lembaga bantuan hukum atau lembaga lainnya yang berkontribusi sebagai pemenuhan hak-hak tersangka dalam rutan.

Kitab Undang-Undang Hukum Acara Pidana telah menempatkan tersangka sebagai manusia yang utuh, yang memiliki harkat, martabat dan harga diri serta hak asasi yang tidak dapat dirampas darinya. (Fuady \& Fuady, 2015) Tersangka telah diberikan seperangkat hak-hak oleh KUHAP yang meliputi: (Widhayanti, 1988).

1. Hak untuk mendapatkan pemeriksaan oleh penyidik yang selanjutnya dapat diajukan kepada Penuntut Umum, dan tersangka berhak perkaranya segera dimajukan oleh Pengadilan ke Penuntut Umum;

2. Hak untuk diberitahukan dengan jelas dalam bahasa yang dimengerti olehnya tentang apa yang disangkakan kepadanya pada waktu pemeriksaan dimulai;

3. Hak untuk memberikan keterangan secara bebas kepada penyidik, dalam pemeriksaan tingkat penyidikan dan pengadilan, tersangka atau terdakwa berhak memberikan keterangan secara bebas kepada penyidik atau hakim;

4. Hak untuk mendapatkan juru bahasa dalam setiap pemeriksaanbaik pemeriksaan pada tingkat penyidikan dan pengadilan;

5. Hak untuk mendapat bantuan hukum pada setiap tingkat pemeriksaan, guna kepentingan pembelaan, tersangka atau terdakwa berhak mendapat bantuan hukum dari seorang atau lebih penasehat hukum selama dalam waktu dan pada setiap tingkat pemeriksaan, menurut tata cara yang diatur dalam undang-undang;

6. Berhak secara bebas memilih penasehat hukum dan untuk mendapatkan penasehat hukum tersangka atau terdakwa berhak memilih sendiri penasehat hukumnya;

7. Hak untuk mendapatkan bantuan hukum bagi tersangka dalam semua tingkat pemeriksaan jika sangkaan yang disangkakan diancam dengan pidana mati atau ancaman pidana minimal 15 tahun atau lebih;

8. Hak tersangka atau terdakwa yang dikenakan penahanan berhak menghubungi penasihat hukumnya sesuai dengan ketentuan dalam KUHAP;

9. Hak tersangka atau terdakwa yang dikenakan penahanan berhak menghubungi atau menerima kunjungan dokter pribadinya untuk kesehatan baik yang ada hubungannya dengan proses perkara maupun tidak;

10. Hak tersangka atau terdakwa yang dikenakan penahanan berhak diberitahukan tentang penahanan atas dirinya oleh pejabat yang berwenang, pada semua tingkat proses peradilan, kepada keluarga atau orang lain yang serumah dengan tersangka atau terdakwa ataupun orang lain yang serumah dengan tersangka atau terdakwa untuk mendapatkan bantuan hukum atau jaminan bagi penangguhannya;

11. Hak tersangka atau terdakwa berhak menghubungi dan menerima kunjungan dari pihak yang mempunyai hubungan kekeluargaan atau lainnya dengan tersangka atau terdakwa guna mendapatkan jaminan bagi penangguhan penahanan ataupun untuk usaha mendapatkan bantuan hukum ;

12. Hak tersangka atau terdakwa berhak secara langsung atau dengan perantaan penasehat hukumnya menghubungi dan menerima kunjungan sanak keluarganya dalam hal yang tidak ada hubungannya dengan perkara tersangka atau terdakwa untuk kepentingan pekerjaan atau kepentingan kekeluargaan;

13. Hak tersangka atau terdakwa berhak secara langsung atau dengan perantaraan penasehat hukumnya dan menerima surat dari penasehat hukumnya dan sanak keluarga setiap kali yang diperlukan olehnya untuk keperluan itu bagi tersangka atau terdakwa disediakan alat tulis-menulis; 
14. Hak tersangka atau terdakwa berhak menghubungi dan menerima kunjungan dari rohaniawan;

15. Hak terdakwa untuk diadili di sidang pengadilan yang terbuka untuk umum;

16. Hak terdakwa untuk mengusahakan dan mengajukan saksi dan atau sesorang yang mempunyai keahlian khusus guna memberikan keterangan yang menguntungkan bagi dirinya;

17. Hak tersangka atau terdakwa berhak menuntut ganti kerugian dan rehabilitasi

Pada dasarnya setiap orang dilindungi oleh negara bahkan orang yang melakukan tindak pidana sekalipun tetap memiliki hak-hak yang telah diatur dalam peraturan perundangundangan serta meningkatkan pemahanan masyarakat rutan terhadap hak-hak mereka serta tindakan yang dapat dilakukan mereka dalam masa tahanan atau menghadapi persidangan bahkan pasca putusan hakim. Situasi sebagai tersangka bukan semata karena mereka melakukan sengaja untuk melakukan suatu tindak pidana, melainkan banyak yang terjadi karena keadaan ekonomi, sosial dan lain sebagainya yang membuat mereka melakukan hal tersebut, walaupun berbagai alasan yang digunakan oleh para tersangka dalam melakukan tindakan pidana tersebut hukuman itu diperlukan karena hukuman itu merupakan pemenuhan rasa keadilan. Bila orang jahat dibiarkan bebas menikmati hasil kejahatannya dan si korban kejahatan menangisi kemalangannya maka hukum diperlukan sebagai perlindungan bagi kepentingan semua orang (Tanya, 2011).

Penegakkan Hukum selalu melibatkan manusia didalamnya dan dengan demikian akan melibatkan tingkah laku manusia juga. Hukum tidak bisa tegak dengan sendirinya, artinya tidak mampu mewujudkan sendiri janji-janji serta kehendak-kehendaknya yang tercantum dalam peraturan-peraturan hukum itu maka dibutuhkan orang lain atau lembaga lain yang membantu untuk memenuhi janji-janji atau kehendak peraturan dengan cara seperti sosialisasi atau penyuluhan. Sosialisasi atau penyuluhan dibutuhkan untuk menjadi sarana memberikan pengetahuan apa yang dihendaki peraturan untuk dipahami oleh semua orang (Rahardjo).

Penyuluhan hukum dibutuhkan oleh para tersangka atau tedakwa karena banyak hak-hak yang seharusnya di peroleh mereka, tetapi mereka tidak tahu bahkan cenderung mengabaikan karena ketidaktahuan atau minimnya pengetahuan mereka terhadap hakhak tersebut. Penyuluhan pada Rumah Tahanan adalahhal yang sangat penting dilakukan mengingat hak-hak tersangka adalah hak yang harus dipenuhi oleh Negara dan banyak dari para tersangka bahkan terdakwa tidak mengetahui hal tersebut, sehingga upaya dari pemahaman atas pemenuhan hak-hak mereka adalah melalui penyuluhan yang dilakukan oleh lembaga-lembaga hukum agar terpenuhi semua hak-hak mereka. Tujuan dari Penyuluhan adalah kegiatan pembinaan bagi tersangka atau terdakwa yang melibatkan para pemberi bantuan hukum dengan cara memberikan konsultasi dan pelayanan terhadap pemberitahuan hak-hak mereka melalui penyuluhan sehingga menghasilkan semangat pembinaan bangsa melalui pemenuhan hak-hak mereka. (Kusumah, Baut, \& K, 1988).

Perlindungan menyuluruh bagi para tersangka termasuk masyarakat binaan di rumah tahanan Pondok Bambu yang berpenghuni 401 orang menimbulkan banyak permasalahan khususnya pemahaman masyarakat binaan terhadap hak-hak mereka yang harus mereka dapat sesuai peraturan perundang-undangan hal ini terlihat dari banyaknya penghuni yang tidak didampingi oleh kuasa hukum baik yang melalui lembaga bantuan hukum ataupun kuasa hukum yang pilih sendiri oleh tersangka .

Penyuluhan sebagai sarana untuk memberi pengetahuan kepada para tersangka merupakan suatu upaya yang terorganisir dalam rangka pemenuhan hak-hak tersangka yang selama ini mungkin belum maksimal dilakukan oleh pihak-pihak yang terkait maka dalam kegiatan penyuluhan diharapkan menjadi bagian kegiatan hukum yang menjadi suatu fungsi kesadaran bagi semua pihak yang terkait khususnya para tersangka terhadap apa yang menjadi hak mereka. Hak-hak yang telah diatur dalam perundang-undangan harus diimplementasikan kedalam kehidupan para tersangka dalam rutan sehingga tidak lagi ditemui permasalahan para tersangka yang tidak terpenuhi hak-haknya.

\section{METODE PELAKSANAAN}

Metode Pelaksanaan ini menggunakan metode penyuluhan dengan cara penyampaian 
informasi hukum dari penyuluh hukum kepada sasaran penyuluhan hukum. Metode penyuluhan hukum diselenggarakan dengan metode langsung yang dilakukan dengan cara bertatap muka secara langsung antara penyuluh dan yang disuluh. Bentuk penyuluhan diberikan dalam bentuk ceramah yaitu memberikan penjelasan tentang peraturan perundangundangan setelah itu berdiskusi untuk mendalami materi hukum yang disuluhkan atau masalah yang dihadapi para peserta penyuluhan. Pelaksanaan pengabdian ini dilakukan dengan menggunakan sarana dan prasarana alat-alat tulis, kamera dan pencatatan biodata peserta penyuluhan serta pengabdian ini dilakukan dengan tahap pelaksanaan sebagai berikut:

Tahap pertama adalah dengan melakukan pembukaan atau perkenalan dan melakukan penyuluhan hukum langsung dalam bentuk ceramah atau memberikan informasi tentang peraturan perudang-undangan, lalu memahami bersama permasalahan hukum yang dihadapi peserta penyuluhan seperti proses acara persidangan dan apa yang harus mereka lakukan, setelah itu dilakukan pencatatan biodata peserta dan permasalahan atau kasus yang dihadapinya. Tahapan ini dilakukan setiap minggu ketiga tiap bulannya selama 8 bulan. Tahap kedua adalah evaluasi dan memetakan masalah yang dihadapi para peserta penyuluhan dan menganalisis permasalahan tersebut. Tahap Ketiga adalah pembuatan laporan terhadap penyuluhan yang dilakukan

\section{HASIL DAN PEMBAHASAN}

Penyuluhan/menginformasikan hak-hak atas Tersangka dalam Rutan adalah sesuatu yang diperlukan untuk memastikan terpenuhinya hak-hak para tersangka tersebut. Seperti yang sudah dibahas sebelumnya, bahwa hak-hak tersebut telah dijamin dalam peraturan perundang-undangan namun masih banyak pihak yang belum memahami apa dan bagaimanacara mereka memperolehnya. Penyuluhan dalam pemenuhan hak-hak tersangka merupakan bagian dari pelaksanaan pengabdian masyarakat khususnya masyarakat yang merupakan lembaga hukum atau yang konsen dalam bidang hukum khususnya dalam pemenuhan hak-hak para tersangka dalam rutan. Terpenuhi hak-hak tersangka selama dalam rutan dan juga memberikan pemahaman hukum tentang peraturan yang tekait pada para tersangka dalam Rumah Tahanan.

Metode pelaksanaan dengan cara penyuluhan dilakukan selama 8 bulan dimulai dari Januari 2019 sampai dengan Agustus 2019, pelaksanaan penyuluhan dilaksanakan setiap minggu kedua atau ketiga tiap bulannya. Masyarakat binaan yang telah direkomendasikan oleh Kepala Rutan dikumpulkan dalam satu ruangan lalu para penyuluh memberikan materi mengenai hakhak tersangka, apa yang harus dilakukan dalam persidangan dan setalah itu dilanjutkan dengan diskusi atau tanya jawab. Kegiatan lanjutannya adalah berkonsultasi secara perorangan terkait masalah yang mereka hadapi baik perkara yang sedang dijalani atau persiapan menuju persidangan dan pertanyaan sekitar msalah yang mereka hadapi .

Bahwa permasalahan yang dihadapi oleh para tersangka sangatlah komplek tidak dapat hanya dikatakan satu macam saja dikarenakan para tersangka yang ada di dalam rutan terkena ancaman pidana dengan pasal yang berbedabeda sehingga untuk memecahkan permasalahan tersebut dibutuhkan waktu untuk berkonsultasi dan memetakan masalah yang dihadapi dengan cara berkala dan melakukan kunjungan ke Rumah Tahanan untuk bertemu dengan para tersangka secara langsung.

Banyak peristiwa yang kita dengar dari media baik cetak maupun elektronik terkait bagaimana perlakuan tersangka yang berada dalam Rumah Tahanan, hal inilah yang menjadi dasar kami membuat penyuluhan terhadap hakhak tersangka sangat dibutuhkan. Solusi atas semua permasalahan tersangka dalam Rumah Tahanan adalah pembekalan pengetahuan hukum bagi mereka sehingga mereka memahami apa yang menjadi hak mereka baik dalam Rumah Tahanan maupun dalam persidangan nantinya. Tersangka bukan hanya memiliki persoalan terkait hak mereka di Rumah Tahanan tetapi juga mereka akan menghadapi persidangan terhadap kasus mereka yang mana ancaman pidananya sangat beragam.

Solusi yang dihadirkan untuk menghadapi permasalahan tersebut dapat dilakukan melakukan penyuluhan dan konsultasi kepada para tersangka yang berada dalam Rumah Tahanan khususnya di Rumah Tahanan Pondok Bambu karena walaupun sebagian dari tersangka ada sudah mendapatkan pendamping atau penasihat hukum pada kenyataannya 
mereka masih banyak yang tidak mengetahui akan menghadapi apa, bagaimana bersikap dan apa yang mereka harus pertahankan selama berada dalam posisi sebagai tersangka. Yang mereka ketehui hanya sebatas bahwa penasihat hukum mereka akan membantu mereka tanpa tahu seperti apa detilnya. Sehingga kehadiran kami sebagai pihak mensosialisaksikan informasi-informasi tersebut mendapatkan tanggapan yang antusias dari para tahanan di sana.

Dengan tidak adanya keterikatan bahwa kami berada disana/bekerja untuk mendapatkan bayaran. Dan mereka bebas untuk bertanya/konsultasi tanpa harus memikirkan biaya yang akan mereka bayar untuk jasa konsultasi tersebut. Percakapan berjalan dengan bebas dengan antusias yang tinggi. Dan kami pun selalu mengingatkan kepada para tersangka bahwa tugas kami di sana untuk membantu memberikan pandangan lebih baik akan apa yang akan mereka hadapi dengan kasus mereka masing-masing. Dan tugas dari seorang pendamping hukum bukanlah "mejamin"akan kebebasan/pendapatkan putusan bebas tidak bersalah, namun untuk memastikan bahwa mereka mendapatkan apa yang sesuai dengan apa yang mereka lakukan. Tidak lebih dan kurang. Karena didapati selama proses sosialisasi berlangsung di rutan, ada beberapa kasus yang pasal yang dikenakan kepada tersangka tidak sesuai/memberatkan dari apa yang sebenarnya terjadi (berdasarkan pengakuan dari para tersangka, dan masih membutuhkan pembuktian lebih lanjut), dengan minimnya pengetahuan hukum mereka maka jelas peristiwa tersebut merugikan para tersangka.

Pengabdian masyarakat melalui masyarakat rutan adalah sala satu cara memberikan informasi mengenai peraturan perundangundangan yang mengatur tentang hak-hak mereka (terdakwa atau tersangka) sehingga mereka dapat apa yang menjadi hak mereka dalam hukum yaitu perlakukan yang sama dalam hukum, yang mana banyak pendapat diluaran yang mengatakan hukum itu tumpul keatas tajam kebawah. Berdasarkan hal itulah dengan bentuk penyuluhan yang dilakukan melalui pemberian informasi diharapkan mampu meningkatkan pemahaman masyarakat rutan terhadap hak-hak tersangka terbukti efektif untuk dapat memetakan masalah yang dihadapi peserta penyuluhan.

Sebagai hasil sosialisasi atas penyuluhan yang dilakukan oleh peniliti yang dilakukan pada Rumah Tahanan pondok bambu selama bulan Januari sampai Agustus 2019 diuraikan melalui Tabel 1. dengan indikator apakah tersangka didampingi oleh kuasa hukum atau tidak dan tindak pidana apa yang dilakukannya. Pendampingan terhadap para tersangka atau terdakwa adalah hak yang sudah diatur undangundang, sehingga pemenuhan terhadap hak-hak tersebut maka penyuluhan hukum selalu menggandeng lembaga bantuan hukum dalam rangka tindak lanjut dari penyuluhan ini adalah pendampingan tersangka atau terdakwa sebagai penasehat hukum bagi mereka .

Berikut data yang didapatkan dari penyuluhan melalui sosialisasi dan diskusi dengan para peserta penyuluhan.

Tabel 1. Data Penyuluhan Rutan Pondok Bambu Januari-Agustus 2019.

\begin{tabular}{|c|c|c|c|c|c|}
\hline \multirow[t]{2}{*}{ Waktu } & \multirow[t]{2}{*}{$\begin{array}{l}\text { Jumlah } \\
\text { Peserta }\end{array}$} & \multirow[t]{2}{*}{ Pasal/Tindak Pidana } & \multicolumn{2}{|c|}{$\begin{array}{l}\text { Pendampingan Oleh } \\
\text { Penasehat Hukum }\end{array}$} & \multirow[t]{2}{*}{ Keterangan } \\
\hline & & & YA & TIDAK & \\
\hline $\begin{array}{l}16 \\
\text { Januari } \\
2019 .\end{array}$ & 15 Orang & Kasus Narkoba & 0 orang & 15 orang & $\begin{array}{l}\text { Membutuhkan } \\
\text { pendampingan dalam } \\
\text { menghadapi persidangan. }\end{array}$ \\
\hline $\begin{array}{l}20 \\
\text { Februari } \\
2019 .\end{array}$ & 13 Orang & $\begin{array}{l}\text { Kasus penipuan dan } \\
\text { pengelapan }\end{array}$ & 0 orang & 13 orang & $\begin{array}{l}\text { Membutuhkan } \\
\text { pendampingan dalam } \\
\text { menghadapi persidangan. }\end{array}$ \\
\hline $\begin{array}{l}20 \text { Maret } \\
2019 .\end{array}$ & 17 Orang & $\begin{array}{l}\text { Kasus narkoba dan kasus } \\
\text { penipuan dan penggelapan }\end{array}$ & 2 orang & 15 orang & $\begin{array}{l}\text { Membutuhkan } \\
\text { pendampingan dalam } \\
\text { menghadapi persidangan. }\end{array}$ \\
\hline
\end{tabular}




\begin{tabular}{|c|c|c|c|c|c|}
\hline \multirow[t]{2}{*}{ Waktu } & \multirow[t]{2}{*}{$\begin{array}{l}\text { Jumlah } \\
\text { Peserta }\end{array}$} & \multirow[t]{2}{*}{ Pasal/Tindak Pidana } & \multicolumn{2}{|c|}{$\begin{array}{l}\text { Pendampingan Oleh } \\
\text { Penasehat Hukum }\end{array}$} & \multirow[t]{2}{*}{ Keterangan } \\
\hline & & & YA & TIDAK & \\
\hline $\begin{array}{l}22 \text { April } \\
2019 .\end{array}$ & 13 Orang & $\begin{array}{l}\text { Kasus penipuan dan } \\
\text { penggelapan dan uang palsu }\end{array}$ & 0 rang & 13 orang & $\begin{array}{l}\text { Membutuhkan } \\
\text { pendampingan dalam } \\
\text { menghadapi persidangan. }\end{array}$ \\
\hline $\begin{array}{l}15 \text { Mei } \\
2019 .\end{array}$ & 19 Orang & $\begin{array}{l}\text { Kasus penipuan dan } \\
\text { penggelapan dan narkoba }\end{array}$ & 6 orang & 13 orang & $\begin{array}{l}\text { Membutuhkan } \\
\text { pendampingan dalam } \\
\text { menghadapi persidangan. }\end{array}$ \\
\hline $\begin{array}{l}26 \text { Juni } \\
2019 .\end{array}$ & 14 Orang & $\begin{array}{l}\text { Kasus narkoba dan kasus } \\
\text { penipuan dan penggelapan }\end{array}$ & 6 orang & 8 orang & $\begin{array}{l}\text { Membutuhkan } \\
\text { pendampingan dalam } \\
\text { menghadapi persidangan. }\end{array}$ \\
\hline $\begin{array}{l}17 \text { Juli } \\
2019 .\end{array}$ & 16 Orang & $\begin{array}{l}\text { Kasus penipuan dan } \\
\text { penggelapan }\end{array}$ & 7 orang & 9 orang & $\begin{array}{l}\text { Membutuhkan } \\
\text { pendampingan dalam } \\
\text { menghadapi persidangan. }\end{array}$ \\
\hline $\begin{array}{l}14 \\
\text { Agustus } \\
2019 .\end{array}$ & 13 Orang & $\begin{array}{l}\text { Kasus narkoba dan kasus } \\
\text { penipuan dan penggelapan }\end{array}$ & 3 orang & 10 orang & $\begin{array}{l}\text { Membutuhkan } \\
\text { pendampingan dalam } \\
\text { menghadapi persidangan. }\end{array}$ \\
\hline
\end{tabular}

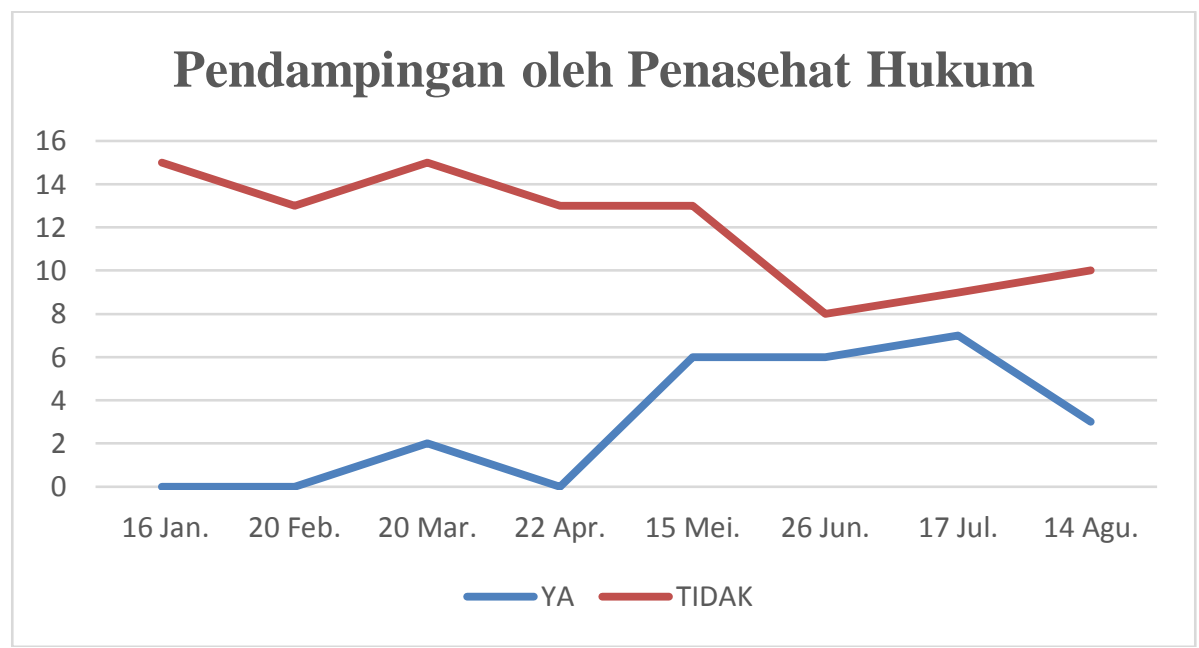

Gambar 1. Diagram Pendampingan oleh Penasehat Hukum

Berdasarkan Tabel 1 dapat ditarik kesimpulan bahwa profil penerima penyuluhan adalah masyarakat yang tinggal dalam Rumah Tahanan Pondok Bambu yang pada saat kunjungan dan penyuluhan banyak adalah pengguna narkotika atau yang terlibat untuk kasus penggelapan atau penipuan dikarenakan faktor ekonomi atau ketidak pahaman mereka menggunakan media sosial sehingga terkena kasus ITE.

Profil tersebut menggambarkan bahwa bahaya narkotika dikalangan masyarakat kita sangat memperihatinkan. Mayoritas para tahanan yang terlibat dalam kasus narkoba terlibat dalam keadaan tersebut kerena kebutuhan ekonomi dan kebetulan bertemu dengan para pengedar yang memperkenalkan sebagai salah satu cara "singkat" yang dapat mereka lakukan untuk menutupi kebutuhan perekonomian yang mereka hadapi. Permasalahan tersebut dapat diatasi dengan solusi pemberantasan pengedar narkotika dengan hukuman mati dan para pemakai dikenakan hukum rehabilitasi sehingga ada upaya represif pemerintahan terhadap pengurangan peredaran narkotika di negara kita dan para pemakai bisa kembali beraktifitas tanpa ketergantungan dengan narkotika. 
Sedangkan untuk kasus penggelapan dan penipuan, mayoritas pihak yang terlibat di dalam kasus tersebut bukanlah pelaku utama dari kejahatan tersebut, banyak dari mereka adalah pihak yang terlibat atau sebagai pihak yang diminta bantuan. Dan dikarenakan tidak pahamnya mereka akan situasi yang mereka hadapi mereka tidak tau bahwa perbuatan tersebut merupakan suatu tindak pidana yang akan berakibat hukum.

Begitu juga halnya dengan kasus ITE ketidak pahaman mereka terhadap teknologi dan kurang bijaknya mereka dalam penggunaan sosial media membuat mereka berada dalam situasi tersebut. Kemudahan dalam mengungkapkan ekspresi membuat mereka lengah akan akibat yang dapat timbul dari hasil tulisan mereka.

Hasil menunjukkan pemahaman para tersangka masih kurang terhadap sangkaan yang mereka hadapi. Dengan keadaan mental mereka yang sudah jatuh karena status mereka sebagai tersangka, mereka merasa sudah seperti terdakwa (orang yang sudah mendapatkan penetapan bersalah) sehingga mereka sering kali pasrah dengan keadaan yang mereka hadapi selama di dalam Rumah Tahanan, walaupun berdasarkan data Tabel 1 dan Gambar 1 yang penulis perlihatkan diatas dapat diketahui bahwa sebagian dari tersangka sudah mendapatkan pendampingan hukum, mayoritas belum. Namun pada kenyataannya para tersangka yang sudah didampingi tersebut masih ada yang tidak paham akan hak-hak mereka dalam Rumah Tahanan. Sehingga upaya sosialisasi melalui penyuluhan merupakan langkah yang tepat karena sangat dibutuhkan oleh para tersangka untuk dapat memahami situasi apa yang akan mereka hadapi nantinya, bagaimana cara menyikapinya dan apa-apa saja yang menjadi hak-hak mereka selama menjalani proses tersebut.

\section{SIMPULAN DAN SARAN}

Pemahaman masyarakat binaan rutan pondok bambu, jakarta tentang hak-hak tersangka masih sangat minim namun dengan kegiatan penyuluhan dan konsultasi yang dilakukan dan sangat antusiasnya msayarakat binaan tersebut diharapkan mampu meningkatkan pemahaman mereka yang dahulu takut menghadapi persidangan telah mengtetahui apa yang harus dilakukannya sehingga kesimpulan dalam pelaksanaan kegiatan penyuluhan dan konsultasi di dalam Rumah Tahanan Pondok Bambu adalah kegiatan yang sangat positif bagi kelompok masyarakat khsususnya para tersangka yang mana luaran dari pelaksanaan kegiatan ini adalah pemahaman mengenai hak-hak tesangka dan apa yang mereka hadapi dalam persidangan. Saran yang dikemukan adalah pemerintah dan pihak-pihak yang terkait mengenai pendidikan hukum senantiasa mengadakan kegiatan ini dalam upaya pemahaman hukum kepada kelompok masyarakat Rumah Tahanan dan juga sarana bagi akademisi untuk melakukan pengabdian terhadap ilmu hukum yang mereka miliki dan implementasi dari kegiatan mahasiswa terhadap ilmu yang didapat dari perkuliahan.

\section{UCAPAN TERIMAKASIH}

Terimakasih kami haturkan kepada LP2M Universitas Al Azhar Indonesia atas dana yang diberikan untuk pelaksanaan penyuluhan ini, kepada LBH Inpartit beserta jajaran yang bersama-sama dengan para penyuluh dalam melakukan penyuluhan, Kepala Rutan Pondok Bambu dan para peserta penyuluhan dan pihakpihak yang telah membantu berjalannya pelaksanaan pengabdian masyarakat ini melalui penyuluhan di Rumah Tahanan Pondok Bambu.

\section{DAFTAR PUSTAKA}

Fuady, M., \& Fuady, S. L. (2015). Hak Asasi Tersangka Pidana. Jakarta: Prenada Media Group.

Kusumah, M. W., Baut, P. S., \& K, B. H. (1988). Konsep dan Pola Penyuluhan Hukum. Jakarta: Yayasan Lembaga Bantuan Hukum Indonesia.

Rahardjo, S. Masalah Penegakkan Hukum (Suatu Tinjauan Sosiologis). Bandug: Sinar Baru.

Tanya, B. L. (2011). Penegakkan Hukum dalam Terang Etika. Yogyakarta: Genta Publishing.

Widhayanti, E. (1988). Hak - hak Tersangka/Terdakwa di dalam KUHAP. Yogyakarta: Liberty. 